\title{
Relativizing effects of high intensity interval training vs continuous moderate
}

\section{Relativizando efeitos do treinamento intervalado de alta intensidade vs contínuo moderado}

Bruno Nicanor Mello da Silva ${ }^{1}$

(1D) https://orcid.org/0000-0001-6116-2765

Leony Morgana Galliano²

(D) https://orcid.org/0000-0002-5599-0377

Fabrício Boscolo Del Vecchio ${ }^{1}$

(D) https://orcid.org/0000-0003-3771-9660

Abstract - The production of systematic reviews and meta-analysis increased substantially. In this sense, we highlight those comparing Moderate-Intensity Continuous Training (MICT) and High-Intensity Interval Training (HIIT). It is known that meta-analyses of well-conducted studies are considered as a superior level of scientific evidence; therefore, it is relevant to critically analyze all those articles, especially speaking about the absence of differences between MICT and HIIT reported in previous studies. Widely, analyzing studies included in a metaanalysis frequently is possible to identify a lack of crucial information to the understanding of the exercise intervention, and this can skew readers interpretation and may conduct an equivocate comprehension of the results. In meta-analysis regarding the effects of MICT and HIIT in body composition, the relativization of the full length of training time of each intervention is frequently lacking. Data from previously published meta-analysis was reanalyzed, verifying higher relative reductions of body fat percentage to the HIIT group in comparison to the MICT group when considered the duration of interventions. In this sense, we suggest that all meta-analysis about this subject need not only to provide complete analysis in body composition but also consider analysis relativized of time spent training.

Key words: Body composition; High intensity interval training; Meta-analysis; Methods.

Resumo - Verifica-se substancial aumento na produção de revisões sistemáticas e metanálises, inclusive sobre os efeitos do exercício na composição corporal. Destacam-se aqui aqueles comparando Treinamento Continuo de Intensidade Moderada (MICE) e Treinamento Intervalado de Alta Intensidade (HIIT). Observando que metanálises bem conduzidas apresentam maior nivel de evidência cientifica, torna-se relevante analisar criticamente os trabalhos sobre a temática, a despeito da possivel ausência de diferença entre MICE e HIIT previamente relatada. Isto deriva do impacto que protocolos e relatos adequados dos estudos primários exercem no resultado da metanálise. Ao analisar estudos incluídos em metanálises, são identificadas ausências de informaçōes relevantes, o que enviesa a interpretação crítica do leitor, podendo conduzir à interpretação equivocada dos resultados. Observando metanálises sobre os efeitos do MICE e HIIT na composição corporal, questiona-se a carência de relativização do tempo total do treinamento para atingir os resultados. Ao reanalisarmos os dados de metanálise previamente publicada, verificamos maior redução relativa do percentual de gordura no grupo HIIT em comparação ao grupo MICE quando consideradas as duraçôes das intervenções. $A$ vista disto, indica-se que todas as metanálise acerca do tema deveriam concernir não somente análises absolutas da mudança de composição corporal, mas relativizá-las ao tempo treinado.

Palavras-chave: Composição corporal; Metanálise; Treinamento intervalado de alta intensidade.

1 Universidade Federal de Pelotas Escola Superior de Educação Física. Pelotas, RS. Brasil.

2 Universidade Federal do Rio Grande do Sul - Hospital de Clínicas de Porto Alegre. Porto Alegre, RS. Brasil.

Received: November 07, 2019 Accepted: January 17, 2020

How to cite this article Silva BNM, Galliano LM, Del Vecchio FB. Relativizing effects of high intensity interval training vs continuous. Rev Bras Cineantropom Desempenho Hum 2020, 22:e68179. DOI: http://dx.doi. org/10.1590/1980-0037.2020v22e68179.

Copyright: This work is licensed under a Creative Commons Attribution 4.0 International License. 


\section{INTRODUCTION}

According to the traditional pyramid of evidence, meta-analyses are hierarchically better than other types of studies in providing a theoretical basis for guidelines to professional practices ${ }^{1}$. In this scenario, even, it has been valued to introduce on articles title an expression after the term metaanalysis: "of well-conducted studies" - both from the point view of scientific rigor as for original studies interventions itself ${ }^{2}$. However, in consequence of prestige and facility to making this type of study, the production of meta-analysis and systematic review reached epidemic proportions ${ }^{3}$. In this sense is observed an increase in production of meta-analysis and systematic review, regarding effects of aerobic exercise on body composition ${ }^{4-8}$. Broadly, those investigations compare protocols of Moderate-Intensity Continuous Training (MICT) with High-Intensity Interval Training (HIIT) on different variables, such as body mass ${ }^{4}$, body mass index ${ }^{6,7}$, waist circumference $e^{5,6,8}$, body fat percentage ${ }^{4-8}$ and visceral fat ${ }^{4,7}$.

Considering that only the study design is not enough to ensure the quality of evidence and that meta-analyses have elevated relevance for practical applications, reviews concerning the classifications of the pyramid of evidence emerged, pondering about the linear hierarchy between studies type. The first proposed modification was to think the study type divisions as waves and to separate systematic reviews and meta-analyses from the pyramid (Figure 1), indicating that they should be evaluated separately 9 This alteration would contemplate the fact that the risk of bias is inherent to the protocols and that it affects the methodological and clinical quality of the results. The second model of pyramid maintains the waves between types of original studies and considers the systematic reviews and metaanalyses as a lens, which would provide a more detailed over the protocols?

There seems to be a consensus that physical exercise has a positive effect on health and HIIT is a trend in the fitness world in the last years. On the view of the relevance of the thematic involving the MICT and HIIT training protocols in body composition and the methodological implications on meta-analyses conductions, we are compelled to realize considerations regarding recent articles that address about this theme, mainly on the possible absence of difference between MICT and HIIT related in some recent investigations ${ }^{4,6}$. Wewege et al. ${ }^{8}$ also related the absence of difference between MICT and HIIT. However, the authors themselves described that, to the HIIT group, there was approximately $40 \%$ less time at exercise, though, this variable was not considered in statistical analysis.

\section{DISCUSSION}

\section{Methodology of interventions}

The first observations regarding the interventions realized. In a recently published meta-analysis ${ }^{6}$, Moreira et $a 1 .{ }^{10}$ study does not report the intensity of rest in HIIT exercises, as well as the duration of sessions. The authors 

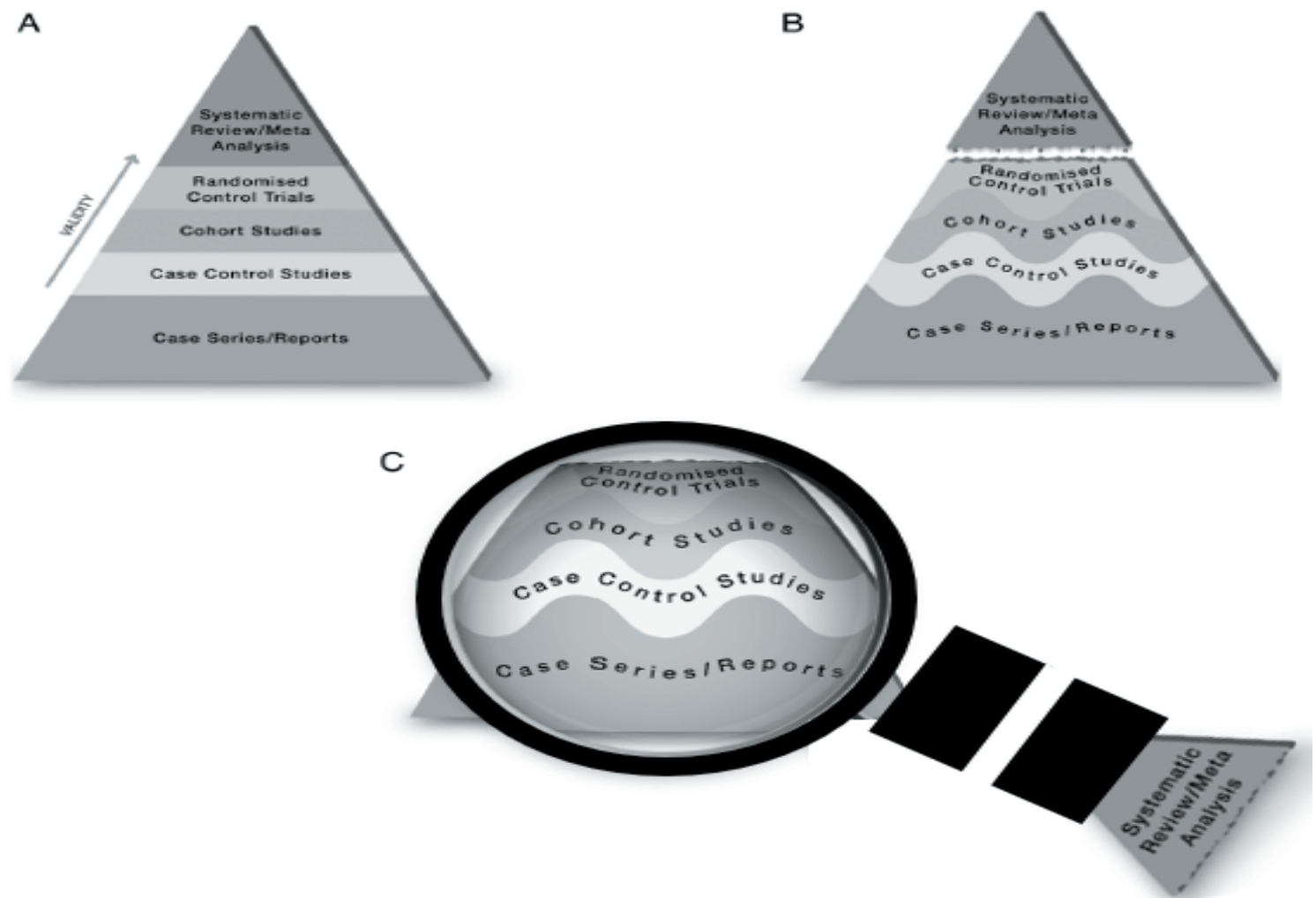

Figure 1. The new proposed evidence pyramid suggested for Murad et al. (2016). $A=$ Traditional Pyramid. $B=$ Revising Pyramid. $C=$ Revised Pyramid. (Adapted figure of Murad et al. ${ }^{9}$ ).

only related that the effort: pause ratio was 2:1 and that HIIT exercise had a similar duration to the continuous group exercise. Moreover, the effort period intensity in HIIT was $20 \%$ above of anaerobic threshold (AT) and the training sessions were monitored via heart rate (HR) associated with AT. For this, the HR and AT were measured in an incremental test, which was interrupted when the lactate concentration reached $4 \mathrm{mmol}$ (LT4). Therefore, it is assumed that the training follow-up was made adding $20 \%$ to HR value associated with AT. Considering that the sample was composed of overweighed men and women, the LT4 method has low reproducibility and sensitivity, especially to interindividual variations ${ }^{11}$. Thus, the applied intervention has some inconsistencies that may lead to different effort intensities. Besides, adding 20\% to HR at LT4 may be quite improbable for unfit subjects (i.e., a subject HR at LT4 is $174 \mathrm{bpm}$, then, the effort period would need to be performed at $204 \mathrm{bpm})$.

The study of Keating et al., published at 2014, also is utilized in several meta-analyses ${ }^{5,6,8}$ and has a high score on the TESTEX scale of methodological quality. However, analyzing this intervention of 12 weeks, we observed that in the four initial weeks ( $2 / 3$ of intervention), the participants performed four to six sprints of $30-45$ s on $120 \%$ of $V^{\cdot} \mathrm{O} 2$ peak, with 120-180s of active recovery periods at 30W. By way of example, another article published in the same year prescribed seven 30s sprints at $120 \%$ iVO2max with 15 s recovery periods, that is, eight to twelve times smaller ${ }^{12}$. From weeks five to twelve, the subjects performed six sprints of 
$1 \mathrm{~min}$ at $120 \% \mathrm{~V} \cdot \mathrm{O} 2$ peak with $2 \mathrm{~min}$ recovery periods at $30 \mathrm{~W}$. Additionally, for $1 \mathrm{~min}$ sprints, literature has indicated passive recovery with a duration from 30 s to $1 \mathrm{~min}$, or active recovery at $50 \%$ of $\mathrm{V}^{\cdot} \mathrm{O} 2 \mathrm{max}$, not even close to the $2 \mathrm{~min}$ at $30 \mathrm{~W}$ adopted in the study mentioned above. Furthermore, to a HIIT with 30s of effort and $2 \mathrm{~min}$ of recovery, close to what is considered Sprint Interval Training (SIT), the appropriate intensity is equal or higher than $150 \% \mathrm{iV}^{\cdot} \mathrm{O} 2 \mathrm{max}^{13}$.

Regarding HIIT prescription, Fisher et al. study, published at 2015, are also included in some meta-analysis ${ }^{5,6,8}$ and have some issues. This study was conducted to investigate possible differences between models of aerobic exercise, considering the hypothesis that higher volume in MICT would lead to better outcomes. Nevertheless, despite the differences in volume $(5 \mathrm{x} /$ week and 3x/week, and biggest duration of sessions), the average intensity was lower in HIIT, which turns volume comparisons impossible since this was not the only unequal variable between protocols. Lastly, the intervention of Earnest et al., published at 2013, included in the meta-analysis ${ }^{6}$ has the intention of performing isocaloric training, and the authors did not describe the duration of the sessions. We reinforce that meta-analysis has a high impact on professional practice. Wherefore, the inclusion of primary studies with questionable designs and that omit relevant information to the correct understanding of the training protocols are not adequate considering external validity and causal bias to a critical interpretation of readers and this contributes to equivocate conclusions about researches results ${ }^{2}$. Beyond training prescriptions, some studies included in meta-analyses about weight loss enrolled samples in which subjects had body mass index lower than $25 \mathrm{Kg} / \mathrm{m}^{2}$, a condition of eutrophism. Consequently, given to the representativeness, the sample is incompatible with populations that need treatment, the fact that prejudices inferences.

\section{Morphological results and training time}

In this sense, in exploratory observation of meta-analyses about weight loss and fat loss between HIIT and MICT methods ${ }^{5,6,8}$, there were selected around 10 original studies, and only on Türk et al. ${ }^{7}$ the above-mentioned studies were not included, however, in this study, not only HIIT protocols were selected. Thus, this meta-analysis included a similar number of studies and demonstrated superiority in the reduction of fat loss percentage favorable to interventions with higher intensities, intermittent or not.

However, the main question stands on the duration and training time to reach their respective outcomes since none meta-analysis relativized the effects in body composition changes according to time trained, even though it is widely known that the variable time is a barrier to practice ${ }^{14}$. Concomitantly, it is pedagogic to observe that the contentment with results is a motivational factor in maintaining the physical activity routine ${ }^{15}$. In this sense, it was observed that the studies of Fisher et al. 2015, Earnest et al. 2013, Shepherd et al. 2015 and Kong et al. 2016, included on aforementioned meta-analysis, have a higher number of withdrawals in MICT. 
Besides, in the current literature, exemplifying how precipitated a claim of absence of difference between MICT and HIIT training models regarding the percentage of body fat, and highlighting the importance of relativization of time in training, we have reanalyzed the data from $\mathrm{Paz}$ et al. ${ }^{6}$ meta-analysis, considering only original studies that really obeyed the inclusion criteria established. As is possible to notice in Figure 2, the reduction of fat mass percentage is higher in the HIIT group in comparison to the MICT group when considering the duration of physical exercise performed. Still, in the additional analysis with a mean of total duration of each intervention (mean minutes $\mathrm{X}$ number of sessions) divided by 10 , to provide a value higher than 150 minutes per week, it was noted that MICT group reduced $0.11 \%$ at 189 minutes per week while HIIT group reduced $0.14 \%$ at 159 minutes per week, a superiority of $21 \%$.

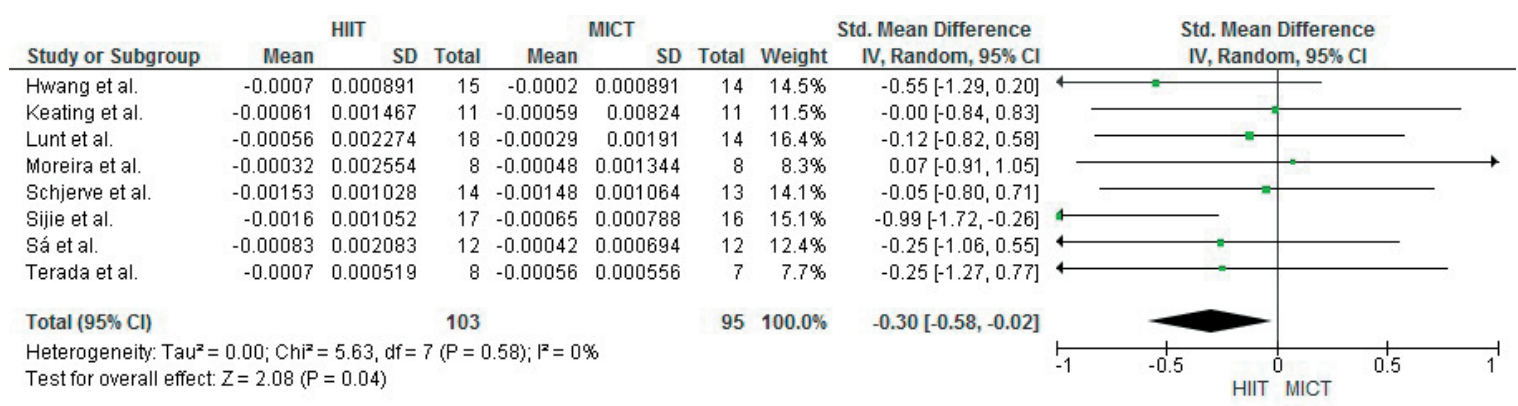

Figure 2. Forest plot of the effects of HIIT and moderate-continuous interventions on the fat percentage, considering the results related to the protocols duration.

\section{FINAL COMMENTS}

The present communication evidenced different methodological precipitations in studies interventions; besides, the epidemic production of systematic reviews and meta-analyses and the neglect behavior with information quality. However, on the theme of "HIIT vs. MICT", the HIIT seems to be superior to fat mass percentage reduction when considering the critical domain of commitment in physical exercise realization. Because of this, it is axiological to observe that all meta-analyses about this topic must concern not only about absolute analysis of body composition changes, but also relativize them by the duration of the performed efforts.

\section{COMPLIANCE WITH ETHICAL STANDARDS}

\section{Funding}

This research did not receive any specific grant from funding agencies in the public, commercial, or not-for-profit sectors. This study was funded by the authors.

\section{Ethical approval}

The article was written in accordance with standards set by the Declaration of Helsinki. 


\section{Conflict of interest statement}

The authors have no conflict of interests to declare.

\section{Author Contributions}

Conceived, designed and supervised the study: FBDV. Analyzed the data: LMG. Wrote the paper: BNMS, LMG. All authors read and approved the final version of the manuscript.

\section{REFERENCES}

1. Howick J, Glasziou P, Aronson JK. The evolution of Evidence Hierarchies: What can Bradford Hill's "guidelines for causation" contribute? J R Soc Med 2009;102(5):186-94.

2. Borenstein M, Hedges L V, Rothstein HR, Higgins JPT. Introduction to MetaAnalysis. John Wiley \& Sons L, editor. 2009. 01-421 p.

3. Ioannidis JPA. The Mass Production of Redundant, Misleading, and Conflicted Systematic Reviews and Meta-analyses. Milbank Q 2016;94(3):485-514.

4. Andreato LV, Esteves JV, Coimbra DR, Moraes AJP, Carvalho T. The Influence of High-Intensity Interval Training on Anthropometric Variables of Adults Afflicted with Overweight or Obesity: a Systematic Review and Network Meta-Analysis. Obes Rev 2019;20(1):142-155.

5. Keating SE, Johnson NA, Mielke GI, Coombes JS. A systematic Review and MetaAnalysis of Interval Training versus Moderate-Intensity Continuous Training on Body Adiposity. Obes Rev 2017;18(8):943-64.

6. Paz CL, Fraga A, Tenório M. Efeito do Treinamento Intervalado de Alta Intensidade Versus Treinamento Contínuo na Composição Corporal: uma Revisão Sistemática com Meta-análise. Rev Bras Atividade Física Saúde 2018;22(6):512-22.

7. Türk Y, Theel W, Kasteleyn MJ, Franssen FME, Hiemstra PS, Rudolphus A, et al. High Intensity Training in Obesity: a Meta-analysis. Obes Sci Pract 2017;3(3):258-71.

8. Wewege M, van den Berg R, Ward RE, Keech A. The effects of high-intensity interval training vs. moderate-intensity continuous training on body composition in overweight and obese adults: a systematic review and meta-analysis. Obes Rev 2017;18(6):635-46.

9. Murad MH, Asi N, Alsawas M, Alahdab F. New Evidence Pyramid. Evid Based Med 2016;21(4):125-7.

10. Moreira MM, Porto H, Souza C, Schwingel PA, Kennedy C, Sá C. Artigo Original Efeitos do Exercício Aeróbico e Anaeróbico em Variáveis de Risco. Arq Bras Cardiol 2008;219-26.

11. Faude O, Kindermann W, Meyer T. Lactate Threshold Concepts: How valid are they? Sport Med 2009;39(6):469-90.

12. Matsuo T, Ohkawara K, Seino S, Shimojo N, Yamada S, Ohshima H, et al. An Exercise Protocol Designed to Control Energy Expenditure for Long-Term Space Missions. Aviat Sp Environ Med 2012;83(8):783-9.

13. Buchheit M, Laursen PB. High-Intensity Interval Training, Solutions to the Programming Puzzle: Part I: Cardiopulmonary Emphasis. Sport Med 2013;43(5):313-38.

14. McIntosh T, Hunter DJ, Royce S. Barriers to Physical Activity in Obese Adults: A rapid evidence assessment. J Res Nurs 2016;21(4):271-87.

15. Hoare E, Stavreski B, Jennings G, Kingwell B. Exploring Motivation and Barriers to Physical Activity among Active and Inactive Australian Adults. Sports 2017;5(3):47.

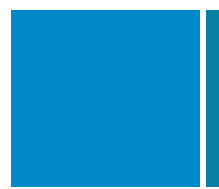

